\title{
Transformative spirituality and missional leadership
}

\author{
Prof. CJP (Nelus) Niemandt
}

Science of Religion and Missiology: University of Pretoria

\begin{abstract}
The importance of transformative spirituality for missional leadership was explored. Missional leadership was defined as the transformation of people and institutions to participate, through meaningful relations and in the power of the Spirit, in God's mission. Missional spirituality was discussed in the context of the missional church, focussing on what the church is, does, how the church organizes what it does, the appropriate leadership, and missional spirituality.
\end{abstract}

It brought together ideas from the missional church movement and the World Council of Churches (Together towards life: mission and evangelism in changing landscapes), with its emphasis on a 'transformative spirituality' and approach that 'mission spirituality is always transformative'. These ideas were applied to missional leadership.

The research applied the following dimensions of personal leadership virtues to transformative missional spirituality and missional leadership: transcendence (which includes appreciation of beauty, gratitude, hope, humor, and religiousness), humanity (which includes the social competencies of kindness, love, and social intelligence), wisdom and knowledge (which include the cognitive competencies of 
creativity, curiosity, open-mindedness, and love of learning), justice (associated with fairness, leadership, and teamwork), courage (including the personal and emotional competencies of bravery, persistence, and zest), and finally temperance (which include the competencies of forgiveness, modesty, prudence, and self-regulation).

\section{Key words}

Discernment, missional ecclesiology, missional leadership, missional spirituality, personal leadership virtues, reflective rituals, transformative spirituality,

Transformative spirituality and missional leadership

\section{Introduction}

The goal of this research is to explore the importance of transformative spirituality for missional leadership, and thus for the missional church. It is in dialogue with Ungerer, Herholdt and Le Roux (2013:48-64) in Leadership for all - Virtue practices to flourish, and the hypothesis is that the 'reflective rituals', described by them, provide a framework and creative perspective to develop characteristics and habits of a transformative, missional spirituality.

The focus is on missional spirituality and not on missionary spirituality. Missionary spirituality has been defined by Matthey (2010:247) as the spirituality of people emphasizing the need to cross frontiers to preach the gospel to those who do not yet know it. He places missional spirituality in a more holistic perspective, and describes missional spirituality as '...a way of life, a relational attitude nourished by a 
theological worldview in a frame shaped by the famous triangle of faith, hope and love in 1 Corinthians 13' (Matthey 2010:251). 'Missional' refers to the church participating in God's mission; where the triune God is the agent of mission, and the church and Christians are called and sent to participate in this mission (see Guder 1998:1-6, Bevans and Schroeder 2011:13-17, and Matthey 2010:251). Doornenbal's (2012:212) description is to the point - missional spirituality is a spirituality that forms and feeds mission. Helland and Hjalmarson (2011:loc 284) say that missional spirituality is an attentive and active engagement of embodied love for God and neighbor expressed from the inside out.

In this research the focus is on missional leadership. In the broadest sense, leadership is where one or a few individuals steer the behavior of many (Ungerer et al 2013:1). It is a set of practices surrounding the legitimate use of gifts, resources, and position, which therefore influences relational power (Hunter 2010:255). Missional leadership is understood as the transformation of people and institutions to participate, through meaningful relations and in the power of the Spirit, in God's mission (Niemandt 2013:57). ${ }^{1}$ The focus on 'transformation' stems from the understanding of leadership as the influence on the thoughts, behaviors, beliefs, or values of people (Gibbs 2005:27). Leadership gives direction and cohesion to a group of people or an organization (Noordt, et al 2008:285). Direction implies change and transformation, a movement or journey to new places or experiences. Transformative leadership drives real and profound change. This is of particular

\footnotetext{
${ }^{1}$ A broader definition is the one by Robert Doornenbal (2012:200): 'Missional leadership refers to the conversational processes of envisioning, cultural and spiritual formation, and structuring within a Christian community that enable individual participants, groups, and the community as a whole to respond to challenging situations and engage in transformative changes that is necessary to become, or remain, orientated to God's mission in the local context.'
} 
importance for the transformation and liberation of both church and society. The ministry of the church introduces strategies and processes that require the exercise of leadership in the transformation of the church (Van Gelder 2007:18).

Missional leadership, and the related transformative and missional spirituality, are discussed in the context of the missional church - an understanding of personal and community witness that is theocentric (and not ecclesiocentric) in approach. This is done under the following headings: (1) what the church is, (2) what the church does, (3) how the church organizes what it does, (4) the appropriate leadership to organize and transform the church into missional life and (5) missional spirituality.

This discussion is done, keeping the profound call to mission spirituality in the policy document of the World Council of Churches (2013, see Keum 2013) - Together towards life: mission and evangelism in changing landscapes - in mind; namely that Christian witness is not only in what we do in mission but how we live out our mission:

Spirituality gives our lives their deepest meaning. It stimulates, motivates and gives dynamism to life's journey. It is energy for life in its fullness and calls for a commitment to resist all forces, powers and systems which deny, destroy and reduce life. (Keum 2013:12-13).

\section{Missional ecclesiology - life in the Trinity}

This discussion of missional leadership and appropriate spiritualities, presupposes and is embedded in an understanding of the church and what the church is. The 
church does what it is and then organizes what it does. This is especially the case when the focus is on spiritualities, as spirituality reveals something of the inner life of the church. When we focus on the missional church, it must be made clear that mission is far more about God and who God is than about the church and what we do (Tennent 2010:Ioc 496). The emphasis thus moves from an ecclesiocentric to a theocentric approach.

This research builds on an understanding of the church as life in the Trinity 'Just as each person is made according to the image of the Trinity, so the church as a whole is an icon of the Trinity...' (Kärkkäinen 2002: loc 175; see also Volf 1998:192213). In the words of Moltmann (2010:26), the community of the church is like the Christian faith itself, a Trinitarian experience of God. The reciprocal interpenetration of the ways of activity and the living spaces of the three divine persons constitute the church's unity in its fullness. Van Gelder (2014:14) also states the essential need to keep the active agency of God, closely coupled to Christian communities seeking to live in faithful relationship with the triune God, at the center of the conversation.

Likewise, the World Council of Churches starts with a very important statement, placing the study document and its ecclesiology in the perspective of life in the Trinity: 'We believe in the Triune God who is the creator, redeemer and sustainer of all life' (Keum 2013:4). This influences the understanding of God's mission and the church's mission, as mission begins in the heart of the Triune God and the love which binds together the Holy Trinity, and then overflows to all humanity and creation (Keum 2013:4). The policy document of the Faith and Order Commission (2013), The church: towards a common vision, calls the church the church of the Triune God' (World Council of Churches = WCC 2013:12). The church is 
a communion in the Triune God, and a communion whose members partake in the life and mission of God (WCC 2013:18).

Mission is an extension and amplification of God's very being. The journey of discovering the community and relationship in the Trinity, as well as the community and relationship of the Trinity to the created world, sets the example of what the church should be. Missional theology builds on the understanding that God is Trinity and missional (Niemandt 2012:2). Mission, then, is to live in the active presence of the Triune God in his creation and the life-changing invitation to participate in this mission of God. God is love and there is a missional relationship from the Godhead to creation. The essence of being church is the notion of missio Dei: God is missional, the church is missional, and 'the church has no mission but the mission of God' (McKnight 2007:135, see also WCC 2013:13). It is clear that the missional discourse shifted the agency of mission from the church to God (Van Gelder and Zscheile 2011:4), and in the process the life of the church in the Trinity becomes indispensable in the reflection on the inner life, or spirituality, of the church.

The reflection on a transformative spirituality appropriate for missional leadership entails a progress from imago Dei to missio Trinitatis. Missional spirituality is thus imbedded in the imago Trinitatis. The observation by the Reformed Ecumenical Council confirms the importance of looking at the Godhead for the template of leadership, saying that '...leadership is missionally directed and grounded in the Missio Trinitatis' (Reformed Ecumenical Council = REC 2005:28). Church is truly church only when it takes part in the one mission of God (missio Dei) - i.e. the fellowship (koinonia) within the church that is characterized by a mutual cooperation, relationship, and unity, based on the mission and example of the Triune 
God (Missio Trinitatis). The implication of this is that authentic missional spirituality is the discovery of God's rhythms, and the ability to align one's life to those rhythms. It is about rhythms of life, or habits, which integrate the sacred and secular. It is to join God's dance of mission, joyfully and indefatigably (Bevans \& Schroeder 2011:18).

\section{What the church does - transformation}

It has been said that the church does what it is, and then organizes what it does. A missional church is transformational (Archbishops' Council 2004:81). It exists for the transformation of the community that it serves. It is about faith communities that engage with God and each other about becoming a redemptive presence in the worlds they inhabit. Willem Saayman's (2007:5) concept of humanizations comes to mind - an invitation to participate in the liberating, healing and evangelizing mission of Jesus of Nazareth, thus 'being missionary while being human'. The church is transformed by, and transforms, the communities it serves by participating in the life-giving mission of the Triune God. God's word does not simply inhabit cultures; it transforms them (Billings 2010:loc. 1629). In doing so, it becomes a sign of the transforming power of the Spirit, it is a foretaste of redemption and reconciliation and an instrument to convey the Gospel locally and globally. Hunter (2010:236) calls it formation - learning to live the alternative reality of the kingdom of God, within the present world, faithfully. Formation is an attitude that aligns the church with the kingdom of God, and that forms the basis for a spirituality that changes lives. All of this is possible because of the life-changing nature of the resurrection of Jesus Christ (Wright 2008:5). NT Wright's (2008:46) understanding of the early Christians still 
applies to the church, where he states that Christians were '...charged with transforming the present, as far as they were able, in the light of the future.'

Transformation is only possible if it is nourished by spirituality. If mission is all about a 'transformative spirituality', then the church needs a missional spirituality - a formational orientation toward the kingdom of God as imperative for missional transformation (Helland and Hjalmarson 2011:loc.107).

\section{What the church does - discernment}

Meylahn (2012:38) says that the church is no longer an institution - created and sustained by the proclamation of a truth, and the correct administration of the sacraments - but a hermeneutical space of listening and discerning. Listening is crucial for the church. Discernment is the core practice of a missional church seeking the presence, or movement, of the Triune God, in relationship with all of creation (Niemandt 2012:6). The WCC (Keum 2013:11) states that the church is called to discern the work of the life-giving Spirit, sent into the world, and to join in with the Spirit in bringing about God's reign of justice. A missional church is a community of followers, called by the Spirit, on a journey of mutual discernment. It is to know the script of God's universal drama - or, as Wright puts it, to know the story we are in (Wright 2010:36-37). The church is the pilgrim people of God (Newbigin 1978:1), on a joyful journey of struggling with Scripture, its author God, and the contexts Scripture is transforming (Billings 2010:loc.218). The spirituality of a missional church is a spirituality of pilgrims on a journey (Van Wyk 2007:12). 
Discernment is the first, and most decisive, step on this missional journey. It is a core practice of Christian leadership and spirituality. It is the art of reading the times and signs - opening yourself up to the context and to God's involvement in the context. Matthey (2010:251) calls it a search for wisdom-shaped spirituality. It is an approach that deals with the way to conduct one's life on the basis of observation, experience, and tradition. The skill of discerning is the door to transformation. It is the starting point of the renewal of faith communities and the world.

Therefore, missional leadership is a turn to discernment and to entering the trialogue. The Gospel in our Culture Network (GOCN) developed this concept of trialogue to describe the important, discerning interaction between church, culture, and biblical narrative (Roxburgh 2011:51). The trialogue is built on discerning together - to seek, discover, understand, and share in what the Holy Spirit is up to in the close-to-the-ground particulars of engagement in, with, against, and for the world. Discernment is ecclesial - churchly - and, in this way, not clergy captivated or individualistically colonized. God's Spirit is at work in actual cultures, organizations and persons. Missional spirituality is embodied in daily life. It is a faithful presence where God's word is enacted in particular places and times (Hunter 2010:240). Matthey (2010:253) says it is a life respectful of one's place within society and the universe, and comprises a spirituality that is based on observation and tradition - as available within one's own system of reference, as well as in other cultural, or religious traditions. Entering the trialogue is a (re)discovery of a missional spirituality where church, culture, and biblical narrative constantly interacts, and the missional church dwell in the Word and in the culture (world). It is a movement in the power of the Spirit where listening to the biblical narratives leads the listener closer to God, 
and where the deepening relation with the Triune God leads to a deeper involvement with culture. In the words of Bosch (1979:4), being spiritual means being in Christ, whether we pray, or walk, or work.

To summarize - the church participates in God's mission by joining in with the transformative power of the Spirit, being faithfully present in the world, and igniting change whenever and wherever possible to serve God's purposes in this world. The first step in this missional journey is discernment - to figure out where the Spirit is working, so as to be able to join in with the Spirit. The relevance to missional spirituality is the focus on a spirituality of the road, where church, culture, and biblical narrative (the trialogue) are all part and parcel of a faithful presence; and, thus, a wisdom-shaped spirituality.

\section{Organizing what it does - and missional leadership}

The church does what it is. The church organizes what it does. The ministry of the church introduces strategies and processes that require the exercise of leadership (Van Gelder 2007:18). Christian faith is deeply embedded in a tradition of passing on, and leading by example, by means of Scriptural and oral sources; but, also, through the mediation of people who inspire, set an example, and who have the courage to lead (Heitink 2007:297). The church needs an appropriate missional understanding of leadership, in order to organize and transform the church into missional life, and to participate in the transformation of communities to be able to share life in its fullness. Missional leadership is, therefore, defined as the Spirit-led transformation of people and institutions, by means of meaningful relations, to participate in God's 
mission (Niemandt 2013:57). Transformation is a vehicle for personal and institutional growth. Missional leadership is transformative leadership. It ignites and drives change, starting with the inner transformation of the leader, leading to the transformation of the church, as well as the context where the church finds itself.

\section{Transformative missional spirituality}

The WCC says:

Authentic Christian witness is not only in what we do in mission but how we live out our mission. The church in mission can only be sustained by spiritualities deeply rooted in the Trinity's communion of love. (Keum 2013:12)

Spirituality is the heart of mission praxis (Kritzinger and Saayman 2011:189). A transformative spirituality serves missional leadership. Missional spirituality does not differ from 'normal' spirituality. A life in faith is a life of being a disciple of Jesus of Nazareth. All spirituality ought to be missional spirituality. Wright (2008:270) says that there is no justification for a private piety that doesn't work out in actual mission.

Attention to missional spirituality completes the circle: the church does what it is, the church organizes what it does, and the church needs leadership to structure and organize transformation, leadership that is anchored in a life of discipleship in the Trinity - a life characterized by a missional spirituality. The doing is dependent on the being. 


\section{Characteristics for a transformative, missional spirituality}

The hypothesis of this research is that the reflective rituals described by Ungerer, Herholdt and Le Roux (2013:48-64), provide a framework and creative perspective to develop habits for a transformative, missional spirituality. Personal knowing and inner transformation is the most difficult part of a transformative missional spirituality. In their book, Leadership for all - Virtue practices to flourish (2013), the authors present a novel and innovative approach to the development of personal leadership. A leadership style that influences a climate for positive, authentic, transformation, and ethical behavior, is built on universal virtues. This approach is also found in Smith's work Desiring the Kingdom, and his description of habits as a second nature, intricately woven into the fiber of our beings and dispositions (Smith 2009:59). Smith argues that life is shaped by desires, by what we love. We are teleological creatures (Smith 2009c:52), formed by habits that constitute the fulcrum of desire (2990c:56). We act according to habits or dispositions that are formed in us through practices, routines, and rituals (2009c:62).

Ungerer et al describe the following six overarching and universal virtues, where a virtue is defined as moral excellence, righteousness, and a particularly good (or beneficial) quality. Each of these virtues has a social, or relational dimension, as well as a personal, or emotional dimension. They developed reflective routines (habits) to facilitate inner transformation and personal knowing, and include the art of reflective learning (Ungerer et al 2013:33).

- Transcendence, which includes appreciation of beauty, gratitude, hope, humor, and religiousness. 
- Humanity, which includes the social competencies of kindness, love, and social intelligence.

- Wisdom and knowledge, which include the cognitive competencies of creativity, curiosity, open-mindedness, and love of learning.

- Courage, which includes the personal and emotional competencies of bravery, persistence, and zest.

- Justice, which is associated with fairness, leadership, and teamwork.

- Temperance, which include the competencies of forgiveness, modesty, prudence, and self-regulation.

Although transformative missional spirituality will not overlap exactly with these virtues, it does provide the potential for a creative and novel framework to unpack missional spirituality.

Ungerer et al (2013) describe 101 'self-help reflective routines' to illustrate ways in which the virtues can be practiced. The scope of this research does not allow a comprehensive similar exercise in terms of transformative missional spirituality. It will only discuss each routine in broad terms, and compare it to an appropriate spiritual ritual, to illustrate the possibilities of such a comparison. The idea is to stimulate ideas on developing transformational missional practices and habits in the sense Helland and Hjalmarson defined it (2011:loc 905): '...practices of the Christian faith are not activities we do to make something spiritual happen in our lives. Nor are they duties we undertake to be obedient to God. Rather, they are patterns of communal action that create openings in our lives where the grace, mercy, and presence of God may be made known to us.' It is about rhythms of life that integrate 
the sacred and the secular, as well as the spiritual formation and missional worlds (Smith 2012)

\subsection{Transcendence}

According to Ungerer et al (2013:57), the virtue of transcendence has the following leadership meta-competencies: Appreciation of beauty and excellence, gratitude (being aware and thankful for the good things that happen), humor, and spirituality (having coherent beliefs about the higher purpose and meaning of life).

In terms of missional spirituality, this research proposes that the universal virtue of transcendence corresponds with a life in the Trinity and a deep awareness of the presence of God (missio Dei). Mission is to live in the active presence of the Triune God and to participate in this mission of God. Missional spirituality is Trinitarian. Christian leadership finds its deepest ground, orientation, and direction from the God who is worshipped. The telos is always embedded in missional spirituality. The beauty of life in the Trinity is 'so beautiful' and 'sculpts the body known as the church' (Sweet 2009:28). The title of Leonard Sweet's (2009) book on the Trinity and the mission of the church is aptly So beautiful. At the deepest level the identity of the Christian faith is constituted by the God who is worshipped: the one God who revealed himself as Father, Son, and Spirit. This life in the Trinity determines the agenda of the missional leader - Christian leaders find their direction, their agenda, from the missio Trinitatis (REC 2005:48). A missional spirituality is fed by poiesis, and enjoys the goodness of God and rests in the beauty and grace of God (Smith 2009a:37-51). 
Ungerer et al describe a self-help reflective routine $(\# 100)$ that will assist in focusing on transcendence: 'Draw a three-generation spiritual genogram (family tree). Indicate to which spiritual, or religious, traditions these people belonged, as well as their spiritual activity (or lack thereof). Reflect on the influence of these stories on your life'.

It is proposed that solitude is an appropriate transformative spiritual and missional ritual. Smith (2009a:166-169) proposes solitude as a ritual to find one's identity in Christ. Solitude is to step away from people for a period of time, to be able to encounter God and rediscover our true identity in Christ. Solitude creates space to listen - it is the door to enter the trialogue, in order to discern.

\subsection{Humanity}

The mega-competencies associated with humanity are kindness, love (valuing close relations with others), and social intelligence (an awareness of the motives and feelings of others). One is reminded of the work of Margaret Wheatley (1999), Leadership and the New Science. Wheatley based the profile of newer organizations and leadership on a specific cosmology; that is, an understanding of the structure of the cosmos informed by quantum physics. Her results interface with management theory: in a quantum world 'relationship is the key determiner of everything'. Consequently, 'leadership is being examined now for its relational aspects' (Wheatley 1999: 11, 13). According to Sweet (2009:98-99), the social universe has changed. It is a world of hyper connectivity, in which Christianity must get over its propositional impotence and embrace relationships. 
In terms of missional spirituality, this research proposes that the universal virtue of humanity corresponds with a deep appreciation of koinonia. The church is a communion whose members partake in the life and mission of God. Leadership, in a Trinitarian key, seeks larger forms of networking and cooperation, and is advocating unity amidst centrifugal forces (REC 2005:47). It is a community theology - a community process of listening to each other, and listening for the '... whisper of the traces of God's incarnational involvement within these stories' (Meylahn 2012:47). Missional leaders operate with a perichoretic notion of relationships. They affirm otherness and plurality, while simultaneously seeking unity, equality, and interdependence. Only a spirituality and frame of mind determined by the Trinity may balance this act. Missional leadership uses the model of Trinitarian relationships to help, motivate, and strengthen the Church to live a life in relationship with the Triune God. The WCC (Keum 2013:38) says: 'Mission spirituality...reconnects us with one another and with the wider creation'. The study document of the Reformed Ecumenical Council says:

Leadership is no longer a lone-ranger function. The world, society, organizations, and the changes we are experiencing are just too complex. The problems we face are too complex to be managed by one person. We require more than one brain to solve them. Dialogue seeks to harness the collective intelligence (CQ) of the people around you; together we are more aware and smarter than we are on our own. (REC 2005:37) 
The virtue of humanity, understood from a Trinitarian and missional perspective, and with its inherent relationality, demands a hermeneutic of love. Heath (2008:119) writes in The mystic way of Evangelism that the church will have to learn to look differently at the world. We need to look with a hermeneutic of love. A hermeneutic of love really expects to discern the loving presence of Christ in the world. It enables the missional leader to give him/herself in prayer and friendship to others, without expecting anything in return. It facilitates service to 'others' in the deep conviction that they are already called by the Spirit, and that Jesus Christ loves and knows them (Niemandt 2013:80). In a missional spirituality, we love God and others as we invite them to come home to the Father's house of love (Helland and Hjalmarson 2011:loc 284). Missional spirituality is relational and formed in love. The remark by Matthey (2010:261) that relations have precedence over dogmatics is especially relevant - 'A missional spirituality will challenge theologians and church leaders to give priority to relations over theological barriers'. Love, not faith, is the final criterion.

Ungerer et al describe a suitable self-help reflective routine (\#29) that enhances humanity: This kindness/compassion exercise is to be kind not only to those we like, but even to those who anger us. The exercise involves not only reflecting on a situation of anger and withdrawing from it, but also active acts of compassion and understanding. Hospitality to the stranger is a typical missional response and expression of love. Oden (2008:11) says gospel hospitality has always been at the heart of Christian life. A missionary church is characterized by welcome and hospitality (Archbishops' Council 2004:82). It is an 'inclusion' practice that challenges our way of life, determining who is 'in' and who is 'out'. 


\subsection{Wisdom and knowledge}

Ungerer et al (2013:57) state that the virtue of wisdom and knowledge has the following leadership meta-competencies: creativity, curiosity (an interest in all ongoing experience), open-mindedness, love of learning (mastering new skills, topics and knowledge), and perspective. Personal knowing and inner transformation is the most difficult part to master in this process. It includes the art of reflective learning (Ungerer et al 2013:33).

In terms of missional spirituality, the universal virtue of wisdom and knowledge corresponds with discernment - the search for wisdom-shaped spirituality (Matthey 2010:251). It includes an approach that deals with the way to conduct one's life on the basis of observation, experience, and tradition. The Edinburgh 2010 study document, Witnessing to Christ today, acknowledged the importance of experience as a foundation of mission (Balia and Kim 2010:12). Mission does not happen in vacuum. Jesus Christ took human form and shared our experience, and mission cannot but be rooted in a certain context, concretely addressing the challenges in that specific context. Fact is, the reception of the gospel is embedded in specific human history and experience. It is a faithful presence in the world (Hunter 2010:238-253). This kind of missional spirituality leads to discovering God's presence in, and advice for, concrete life questions. A Trinitarian approach does have implications in terms of the way Scripture is understood. The word of the Triune God is not an abstract word, but a word with us, a word for us (Bollinger 2010:loc. 1233). Meylahn (2012:40) states that 'being church, doing theology is about listening to the narratives of a particular local context and then seeking to interpret 
these narratives within their cultural, social, political narrative setting, with the help of other disciplines...'. Moynagh and Harrold (2012:loc 3038) say that listening entails asking what the church might discover from the world and what it might celebrate with the world.

Doornenbal (2012:222) came to the conclusion that missional leadership is a particular kind of learning. The focus of missional leadership is indeed on developing a Christian congregation into a learning community, a community of commitment in order to mature and effectively fulfil its mission to the world. Rather than stressing permanence, uniformity, and stability; a learning community cultivates impermanence and change. It nurtures new and expansive patterns of thinking, it modifies behavior to reflect new knowledge and insights, and it sets free collective imagination and aspiration (Doornenbal 2012:359). A teachable spirit, as well as participation in learning communities of discernment, is thus part and parcel of missional spirituality.

Ungerer et al (\#17) propagate a routine called 'Exploring with an open mind'. It is a routine that helps leaders to experience a system through the lens of multiple stakeholders, by allowing the leader to move into unfamiliar environments, to immerse in different contexts, and step into new experiences. In terms of a transformative spiritual and missional ritual, one may consider randomizing rituals. Sweet (2010:97-98) mentions 'randomizing rituals' to assist a leader in transcending boundaries, and to practice activities that will allow a leader to step into unfamiliar environments. A typical 'random ritual' is to make a choice to join the table of strangers at a conference or function and to open one up for interaction with 
strangers. Another ritual is one found in the 'Dwelling in the Word' practice of the South African Partnership for missional churches, where Bible reading is done by making a conscious choice to read it with the person least familiar to the leader, and listening carefully to that person. It is a ritual where the same text is read over a period of time and with different people; not once, but numerous times, not finishing reading, but getting numerous readings from different people and being transformed by this process. It is participatory reading, done in the expectation that the participants will meet the Spirit in the reading process, and that they will be transformed by this experience. Nel (2013:4) calls it a communal reader-response reading of a text (see Nel 2013:1-7, for a detailed description of this ritual). Roxburgh (2011:80) says:

We are invited inside the biblical texts not as miners crushing rock to extract its essential minerals but as travelers ready to be surprised in ways that unfold the unspoken assumptions in our stories, calling them into question in ways that disorient us so that our stories of what God is doing might be transformed.

\subsection{Courage}

According to Ungerer et al (2013:55-567), the virtue of courage has the following leadership meta-competencies: authenticity, bravery (not shrinking from threat, challenge, difficulty, or pain), persistence, and zest (approaching life with excitement and energy). 
Missional leadership, with its focus on transformation, presupposes change and movement into unknown territory. It demands a spirituality of the road, into the unpredictable domain of the Holy Spirit.

In terms of missional spirituality, it is proposed that the universal virtue of courage corresponds with the concept of transforming spirituality and the transforming power of the Gospel. Barrett et al (2004:74-83) describe 'taking risks as a contrast community' as one of the patterns of missional churches. It is a source of courage, and the hope that the Spirit of the Gospel will transform the church and its members, as well as society. One is reminded of the powerful statement in the study document of the WCC:

The Holy Spirit, poured out in tongues of fire at Pentecost, fills our hearts and makes us into Christ's church. The Spirit which was in Christ Jesus inspires us to a self-emptying and cross-bearing life-style and accompanies God's people as we seek to bear witness to the love of God in word and deed. The Spirit of truth leads into all truth and empowers us to defy the demonic powers and speak the truth in love. As a redeemed community we share with others the waters of life and look for the Spirit of unity to heal, reconcile and renew the whole creation... (Keum 2013:37-38)

Frost and Hirsch (2011:24) say: 'The church should be one of the most adventurous places on earth - the locus of all quests, the highly adaptive Jesus community at the very forefront of what God is doing in the world'. To enhance the missional virtue of courage, missional spirituality will have to use art more extensively as a form of 
assessment. Jackson (2010:298) underlines the importance of playful questing, imaginative exploration, and engagement. He points to the 'fuzziness' of missiological expressions in new contexts, and challenges leaders to develop missiologies rooted in the experience of transition and rootlessness.

A missional spirituality will reflect the Anatomy of a pioneer (Hirsch and Catchim (2012:162-165):

- $\quad$ An ability to invent the future while dealing with the past.

- A willingness to break with traditional ideas and methods.

- $\quad$ An ability to play multiple roles at the same time.

- A high tolerance for risk.

- A need to be different even while supporters want the pioneer to be the same.

- $\quad$ An understanding that many want the pioneer to fail.

The reflective routine suggested by Ungerer et al (\#63) is: having fun. 'In essence, having fun means getting over yourself - not being concerned about the impression you are making and whether "they" are laughing at you or with you. In fact, smiling and laughter are the whole point of having fun.' (Ungerer et al 2013:173). In terms of missional leadership, play is important. Play is the oxygen for creativity, and creativity ignites missional innovation. Smith (2009b:47-49) also underlines the importance of play: 'We play because our God is good. Grace is sufficient for us. God wants us to be full of joy, and play is a way to experience the goodness of God and the richness of life'. 


\subsection{Justice}

Ungerer et al (2013:55) state that the virtue of justice is associated with fairness, leadership, and teamwork (working well as member of a group or team). The theme of justice opens up multiple possibilities in terms of the ways it corresponds with a transformative missional spirituality. Kritzinger and Saayman (2011:191) describe David Bosch's life and works, and states that his missional spirituality was characterized by deeds of justice.

Ungerer et al place emphasis on teamwork. Meylahn (2012:55) says that leadership is communal - we are together on the journey. One can say that missional leadership does the same. A transformational missional spirituality will focus on developing a mutual mission, building a shared vision, and identifying and developing shared core values, beliefs, and spirituality. The leadership team must be a community where trust is a key element. This is especially important in the core missional practice of discernment. Teams discern together. It is a movement towards consensus, walking the extra mile on the missional journey, to ensure that the team heard the Spirit and each other (Niemandt 2013:155).

Ungerer et al (\#49) propose a routine building on a 'we' mindset. 'Building a "we" mindset is a continuous challenge in a world of the empowered individual and our deep-rooted fascination and dependence on a "hero" mentality.... In a $21^{\text {st }}$ century world where information and relationships are key for the future success, we need everybody's contribution to prosper and thrive' (Ungerer et al 2013:140). In terms of a transformative spiritual and missional ritual, it is about developing rituals of cooperation. The REC (2005:37) stated that participation, cooperation, and collaboration that produces synergy is essential for high and quality performance in 
building effective teams. It is a question of empowering others to be the best they can be; to enable them to develop to their full potential.

\subsection{Temperance}

Ungerer et al (2013:57) describe the virtue of temperance in terms of the following leadership meta-competencies: forgiveness, modesty, prudence, and self-regulation.

This reminds one of Bosch's (1991:484) famous statement that mission is done in bold humility. In Kritzinger and Saayman's (2011:192) description of the spirituality of David Bosch, they draw attention to his understanding of vulnerability and the vulnerability of mission. Christian mission has always been associated with power - the power of the Holy Spirit (Balia and Kim 2010:87). Mission is finding out where the Holy Spirit is working and joining in. This power of the Spirit is not compelled by human might. It is grounded in Jesus' self-giving non-violent love for all. It is the power of embrace. The transforming, embracing power of the Spirit invites people into the life of God through grace and acceptance, not fear and violence (Niemandt 2011:5). To conclude this reflection, a reference to Bosch - the uniqueness of Christianity is revealed in the cross, not as a sign of strength, but as proof of weakness and vulnerability (Kritzinger and Saayman 2011:193).

Transformational missional spirituality builds communities of mutual service and interdependence, in interaction and vulnerability, in shared stories and common purpose (Helland and Hjalmarson 2011: loc 539). 'The leader is the pastor in the sense of the servant who eagerly awaits and receives the stories of the community and washes feet, thereby respecting and honoring these stories' (Meylahn 2012:54). 
In routine \#70 Ungerer et al (2013:185) say that leaders must be aware of their blind spots. Seeking honest information on leadership capabilities is vital to a leader's self-awareness and, therefore, effectiveness. They propose routines such as asking people and friends about one's blind spots. I propose a 'kenotic' spiritual and missional ritual, where missional leaders can practice humility by dwelling in the Word (on a text such as Phil. 2:5-11). One can ask questions such as: 'How can I imitate Christ's humility?' or 'Share a story where you misused the power of the gospel'.

\section{Conclusion}

In this research, missional leadership was placed within the context of missional ecclesiology, and illuminated with ideas from the missional church movement as well as the ecumenical movement. This leads to the description of missional leadership as the transformation of people and institutions to participate, through meaningful relations and in the power of the Spirit, in God's mission.

It showed the importance of a transformative missional spirituality, because a missional church is transformational and focuses on faithful presence. The research also emphasized the importance of discernment. Discernment is to enter the trialogue - where church, culture, and biblical narrative constantly interact; and the missional church dwell in the Word and in the culture (world). This interaction necessitates a discussion with management sciences, in the reflection on missional leadership and transformational spirituality. This led to a comparison of reflective self-help routines, developed to facilitate inner transformation and personal 
knowing, with transformational missional practices; in order to postulate rhythms of life that integrate the sacred and secular, as well as spiritual formation and missional worlds.

\section{References cited}

Archbishops' Council (2004). Mission-shaped church. London: Church House Publishing.

Balia, Darell and Kirsteen Kim, eds. (2010). Witnessing to Christ Today. Oxford: Regnum Books International (Regnum Edinburgh 2010 Series, volume II).

Barrett, Lois Y. (2004). "Taking risks as a contrast community" in Lois Y. Barrett, Darrell L. Guder, Walter C. Hobbs, George R. Hunsberger, Linford L. Stutzman, Jeff Van Kooten, Dale A. Ziemer, eds. Treasure in clay jars: Patterns in missional faithfulness. Grand Rapids: Eerdmans: 74-83.

Bevans, Steven B. and Roger P. Schroeder (2011). Prophetic Dialogue. Reflections on Christian mission today. Maryknoll, NY: Orbis Books.

Billings, J. Todd (2010). The Word of God for the people of God. An entryway to the theological interpretation of Scripture. Grand Rapids: Eerdmans.

Bosch, David J. (1979). A Spirituality of the Road. Scottdale: Herald Press. (1991). Transforming Mission: Paradigm shifts in theology of mission. Maryknoll, NY: Orbis Books. 
Doornenbal, Robert J.A. (2012). Crossroads: An Exploration of the Emerging-Missional Conversation with a Special Focus on 'Missional Leadership' and Its Challenges for Theological Education. Delft: Eburon Academic Publisher.

Frost, Michael and Alan Hirsch (2011). The faith of leap. Embracing a theology of risk, adventure and courage. Grand Rapids: Baker, Kindle edition.

Gibbs, Eddie (2005). LeadershipNext. Downers Grove: InterVarsity.

Gibbs, Eddie and Ryan K. Bolger (2005). Emerging Churches. Creating Christian community in Postmodern cultures. Grand Rapids: Baker Academic.

Guder, Darrell L. ed. (1998). Missional church: A vision for the sending of the church in North America. Grand Rapids: Eerdmans.

Heath, Elaine A. (2008). The mystic way of Evangelism. A contemplative vision for Christian outreach. Grand Rapids: Baker, Kindle edition.

Heitink, Gerben (2007). Een kerk met karakter. Kampen: Kok.

Helland, Roger and Leonard Hjalmarson (2011). Missional spirituality. Embodying God's love from the inside out. Downers Grove: InterVarsity, Kindle edition.

Hendriks, H. Jurgens (2004). Studying congregations in Africa. Wellington: Lux VerbiBM.

Hirsch, Alan and Tim Catchim (2012). The permanent revolution. Apostolic imagination and practise for the 21st century church. San Francisco: Jossey-Bass. 
Hunter, James D (2010). To change the world. The irony, tragedy, and possibility of Christianity in the late modern world. Oxford: Oxford University Press.

Jackson, Darrell (2010). "The futures of missiology." In Viggo Mortenson and Andreas $\varnothing$. Nielsen, eds. Walk humbly with the Lord: Church and mission engaging plurality. Grand Rapids: Eerdmans: 278-299.

Kärkkäinen, Veli-Matti (2002). An introduction to Ecclesiology. Downers Grove: IVP, Kindle edition.

Keum, Jooseop ed. (2013). Together towards life. Mission and Evangelism in changing landscapes. Geneva: World Council of Churches Publications.

Kritzinger, J.N.J (Klippies) and Willem Saayman (2011). David J Bosch. Prophetic integrity, cruciform praxis. Dorpspruit: Cluster.

Matthey, Jacques (2010). "Missional spirituality in the contemporary world." In Viggo Mortenson and Andreas $\varnothing$. Nielsen, eds. Walk humbly with the Lord: Church and mission engaging plurality. Grand Rapids: Eerdmans: 247-264.

McKnight, Scott (2007). A Community called Atonement. Nashville: Abington Press. Meylahn, Johann-Albrect (2012). Church emerging from the cracks - a church IN, but not OF the world. Bloemfontein: Sun Press.

Moltmann, Jürgen (2010). Sun of righteousness, arise!. London: SCM.

Moynagh, Micheal and Philip Harrold (2012). Church for every context. An introduction to theology and practice. London: SCM, Kindle edition. 
Newbigin, Lesslie (1978) (Revised edition 1995). The open secret. An introduction to the theology of mission. Grand Rapids: Eerdmans.

Nel, Marius J. (2013). "The influence of dwelling in the Word within the Southern African Partnership of Missional Churches." Verbum et Ecclesia 34(1), Art. \#778, 7 pages. http://dx.doi.org/10.4102/ve.v34i1.778

Niemandt, C.J.P.(Nelus) (2011). "Mission and Power" - The relevance of the Edinburgh 2010 discussion in the theological engagement with violence." Verbum et Ecclesia 32(2), Art. \#491, 7 pages. http://dx.doi.org/10.4102/ve.v32i2.491.

(2012). "Trends in missional ecclesiology." HTS Teologiese Studies/Theological Studies, 68(1), Art. \#1198, 9 pages. http://dx.doi.org/10.4102/hts.v68i1.1198.

(2013). Nuwe leiers vir nuwe werklikhede. Vereeniging: CUM.

Noort, Gerrit, Stefan Paas, Henk de Roest and Sake Stoffels, eds. (2008). Als een kerk opnieuw begint. Handboek voor missionaire gemeenskapsvorming. Zoetermeer: Boekencentrum.

Oden Amy G. (2008). God's welcome. Hospitality for a Gospel-hungry world. Cleveland: Pilgrim Press.

Reformed Ecumenical Council (2005). Minutes of the Reformed Ecumenical Council. Session at Utrecht, The Netherlands, 12 - 26 July 2005.

(2005a), Clerical and Lay Leadership, Report to the REC Netherlands, Assembly 2005, The Netherlands, 12 - 26 July 2005. 
Roxburgh, Alan J. (2011). Missional. Joining God in the neighbourhood. Grand Rapids: Baker, Kindle edition.

Saayman, Willem (2007). Being missionary - being human. An overview of Dutch Reformed mission. Pietermaritzburg: Cluster.

Smith, James B. (2009a). The good and beautiful God. Falling in love with the God Jesus knows. Cape Town: Lux VerbiBM.

(2009b). The good and beautiful life. Putting on the character of Christ.

Cape Town: Lux VerbiBM.

(2009c). Desiring the Kingdom. Worship, worldview and cultural formation.

Grand Rapids: Baker Academic.

$\begin{array}{llll}\text { Smith, } & \text { (2012). Kom } & \text { Kingdom }\end{array}$

http://www.rhythmoflife.co.za/adventures/ accessed on 12 March 2013.

Sweet, Leonard (2009). So beautiful. Divine design for life and the church. Colorado Springs: David Cook.

(2010). Nudge. Awakening each other to the God who's already there.

Colorado Springs: David Cook.

Tennent, Timothy C. (2010). A Trinitarian Missiology for the Twenty-first century. Grand Rapids: Kregel, Kindle edition.

Ungerer, Marius, Johan Herholdt and Jannie le Roux (2013). Leadership for all. Virtue practices to flourish. Randburg: Knowres. 
Van Gelder, C., and Zscheile, D.J. 2011. The missional church in perspective. Mapping trends and shaping the conversation, Grand Rapids: Baker Academic [Kindle edition] Van Gelder, Craig (2007). The Ministry of the missional church. A community led by the Spirit. Grand Rapids: Baker.

Van Gelder, Craig (2014). "The Future of the Discipline of Missiology: A Brief Overview of Current Realities and Future Possibilities." In International Bulletin of Missionary Research January 2014: 10-16.

Van Wyk, A. Chris (2007). "Metgeselle op 'n pelgrimsreis." In Kruisgewys 7/4 Desember 2007: 12

Volf, Miroslav (1998). After our likeness: The Church as the Image of the Trinity. Grand Rapids: Eerdmans.

Wheatly, Margaret J.(1999). Leadership and the New Science. San Francisco: BerretKoehler Publishers.

World Council of Churches (2013). Resource book WCC 10 $0^{\text {th }}$ Assembly, Busan 2013. Geneva: World Council of Churches Publications.

Wright, Christopher J.H. (2010). The Mission of God's people: A Biblical theology of mission. Grand Rapids: Zondervan.

Wright, Nicholas T. (2008). Surprised by hope. New York: HarperOne. 